\title{
Cicatricial ectropion correction in a patient with pyoderma gangrenosum: case report
}

\author{
Correção de ectrópio cicatricial em paciente com pioderma gangrenoso: \\ relato de caso
}

Fernando Procianoy ${ }^{1}$

Mariana Tremel Barbato ${ }^{2}$

Luiz Eduardo Osowski ${ }^{3}$

Francisco José de Lima Bocaccio ${ }^{4}$

Lucio Bakos $^{5}$

\begin{tabular}{l} 
ABSTRACT \\
\hline A 19 year old female with pyoderma gangrenosum was referred to the \\
oculoplastic clinic for evaluation of severe cicatricial ectropion of the \\
right lower eyelid. Examination evidenced important scarring of lower \\
eyelid and malar region with secondary ectropion. A full-thickness skin \\
graft associated with a lateral tarsal strip procedure and scar tissue \\
release was performed. The patient's corticosteroid dose was raised for \\
the procedure, and after surgery there was no healing problem or ulcer \\
formation in the eyelid or in the graft donor site. As pyoderma gangre- \\
nosum is associated with a pathergy phenomenon in up to $25 \%$ of the \\
cases, the onset of new lesions is a relevant concern when performing \\
surgery in these patients. In this case, the surgery was safely performed \\
under corticosteroid immunosuppression.
\end{tabular}

Keywords: Pyoderma gangrenosum; Ectropion; Eyelid diseases; Skin transplantation; Immunosuppression/therapeutic use; Case reports [Publication type]

\section{INTRODUCTION}

Pyoderma gangrenosum (PG) is a rare neutrophilic dermatosis frequently associated to other systemic diseases such as ulcerative colitis, Crohn's disease, polyarthritis, gammopathy and other conditions. It is characterized by painful necrotic ulcerations with eritematous and irregular borders. The initial lesion is usually a nodule or sterile pustule, which rapidly breaks down to form a progressively enlarging ulcer ${ }^{(1-3)}$.

The extremities are more frequently involved, more commonly the inferior limbs. However, PG can occur in the skin anywhere: head, face, arms, chest, periocular region and mucocutaneous areas ${ }^{(1)}$. Etiology is still uncertain, but these patients were already described to have alfa-TNF, IL- $8^{(4)}$ and dermic necrosis factor ${ }^{(5)}$ increase. Pathergy phenomenon is found in $25 \%$ of the patients ${ }^{(1)}$.

Diagnosis is based on clinical findings, and histopathology is not specific. Differential diagnosis with other cutaneous ulcers may be complicated, but the treatment must be readily started since the ulcers cause important deformities and impair in life quality ${ }^{(5)}$.

The mainstay of PG treatment is immunosuppressive treatment for systemic disease, and therapy focusing on underlying disease when present. The systemic administration of glucocorticoids is the most effective treatment of PG, however long term therapy produces side effects in up to $50 \%$ of the patients. Sulfa drugs (dapsone, sulfapyridine and sulfasalazine) are beneficial, but not all patients respond equally well to them. Cyclosporine 
and tacrolimus are very effective in the treatment of PG, and other immunosuppressive agents as azathioprine and methotrexate have been beneficial for some patients ${ }^{(6)}$.

Ocular involvement in PG has already been described in different presentations that may vary from orbital destruction to sclerokeratitis ${ }^{(7-11)}$. Eyelid necrosis and destruction have been reported, but not eyelid malpositions due to facial sequelae of ulcers. There is no current data or recommendation in the literature on the surgical treatment of the eyelid and its safety under this condition.

\section{CASE REPORT}

A 19 year old female with pyoderma gangrenosum was referred to the oculoplastic clinic for evaluation of severe cicatricial ectropion of the right lower eyelid that developed after the healing of malar PG ulcers 12 months before. Patient's history consisted of chest and face papules that eventually ulcerated for the last 4 years, being examined by dermatologists, who diagnosed PG based on the clinical aspects of the skin lesions, after exclusion of other specific ulcerative processes and the prompt clinical response to corticosteroid treatment. Histopathology of the lesions was unspecific (chronic ulcer) and she had no systemic disease associated. Medical therapy with prednisone $80 \mathrm{mg} /$ day and dapsone $50 \mathrm{mg} /$ day was started as she was pregnant at that time. After healing of the ulcers, prednisone dose was tapered.

Examination evidenced important scarring of the right lower eyelid region and the midface region, secondary ectropion and retraction, and extensive lower conjunctival exposure (Figure 1 and Figure 2A). The eyelid skin close to the margin had a normal aspect. The patient complaints included eye irritation and aesthetic issues.

As the problem was caused essentially by shortage of the anterior lamella, a lateral tarsal strip procedure and scar tissue release with full-thickness skin grafting was were performed under local anesthesia. After an infraciliar incision, canthotomy and inferior cantholysis were performed. A tarsal strip was fashioned and the suture was passed through the periosteum of the lateral orbital rim with 5-0 polyester fiber suture in order to provide horizontal tightening. The supraclavicular skin graft was transposed into the lower eyelid defect and sutured to the adjacent skin with 6-0 nylon sutures. The patient was already in corticosteroid use for several months, and the disease was considered quiescent for the last 6 months under treatment. The prednisone dose was raised for the procedure from $40 \mathrm{mg} / \mathrm{day}$ to $60 \mathrm{mg} / \mathrm{day}$ one week before the surgery. This dose was maintained during the first month post-operative and posteriorly tapered.

There were no signs of pathergy phenomenon, disease activation or new lesions in both eyelids and donor site in an 18month post-operative follow-up. The eyelid remained with minor retraction and no ectropion recurrence after this follow-up (Figure 2B). The donor site developed a hypertrophic scar (Figure 3).

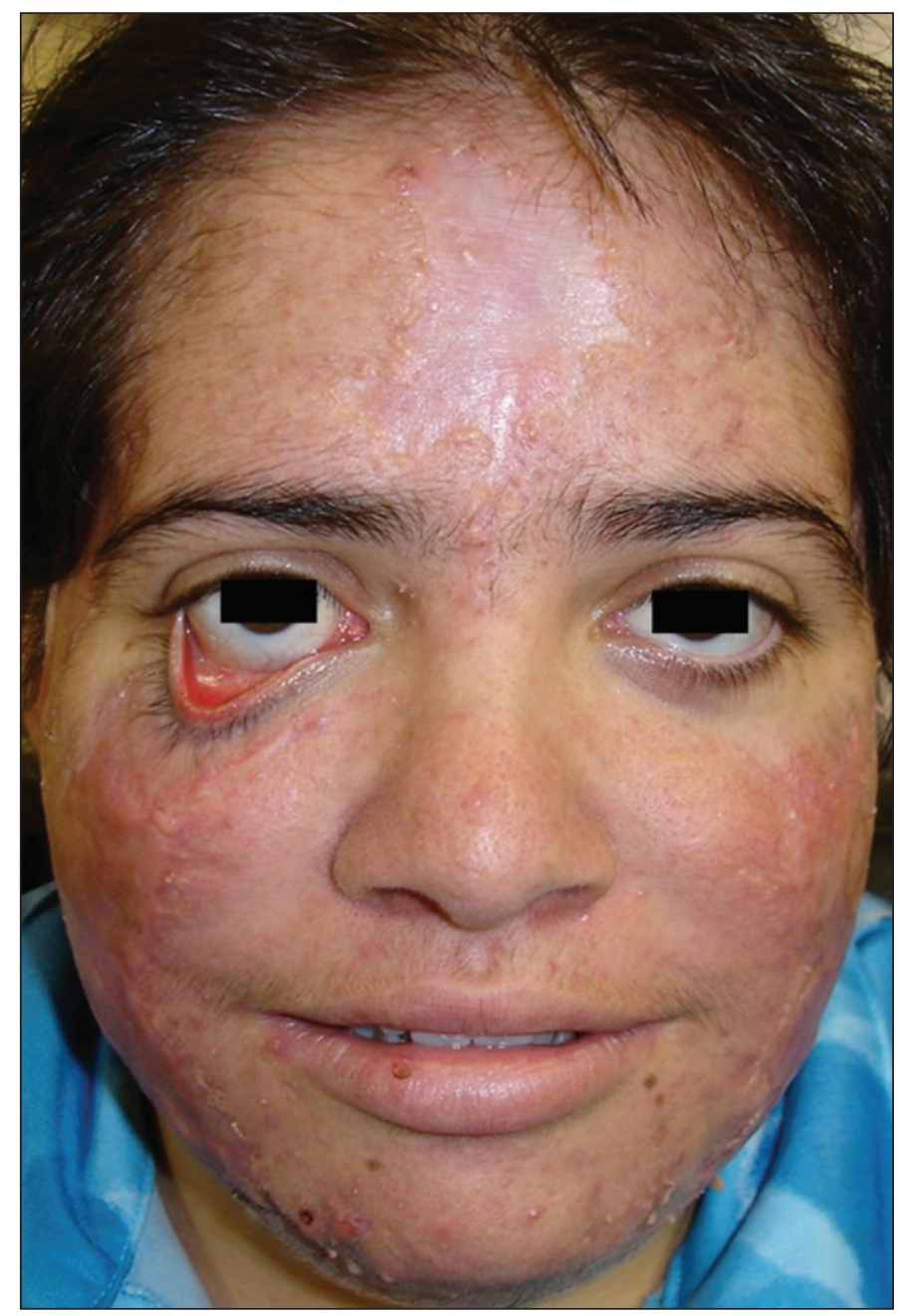

Figure 1 - Cicatricial ectropion of right lower eyelid

\section{DISCUSSION}

Surgical treatment of cicatricial ectropion is well established, with consistent results over time. The need for eyelid surgery and skin grafting turns into a challenge when the patient has a disease in which both the operated eyelid and the graft donor site can turn into a painful necrotic ulcer after surgery.

PG is associated with a potential pathergy phenomenon in $25 \%$ of the patients. This means that skin trauma like intradermal skin testing or injections, pricks, insect bites, biopsies and operations may induce new lesions. The reactivation of the disease or the onset of new lesions are important concerns when performing surgery in these patients ${ }^{(1)}$. This risk must be in mind when choosing the donor site, as the onset of PG lesions in an otherwise healthy area may occur. In this case, supraclavicular area was chosen as the graft donor site because there was previous scarring on both retro auricular spaces, and a possible lesion induction on the supraclavicular space would be less significantly disfigurating. Other surgical tech- 

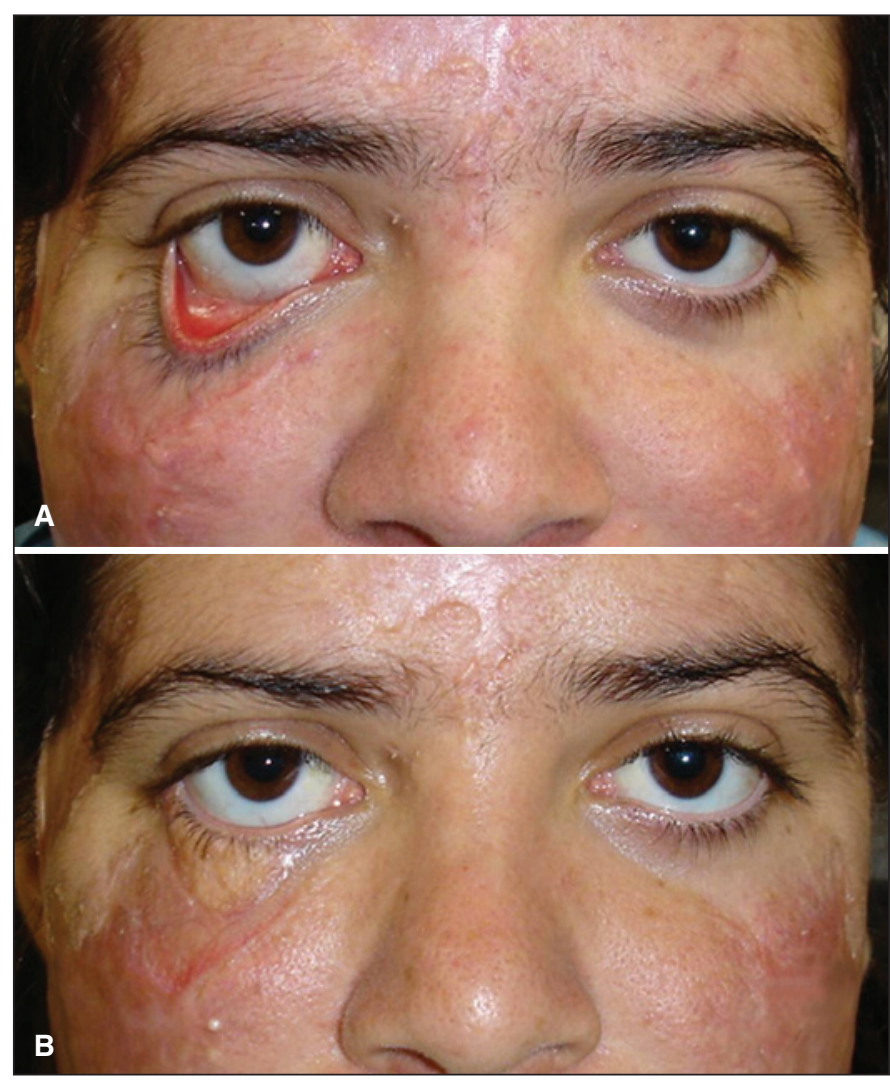

Figure 2 - Detail: A) Preoperative; B) 6-month post-operative

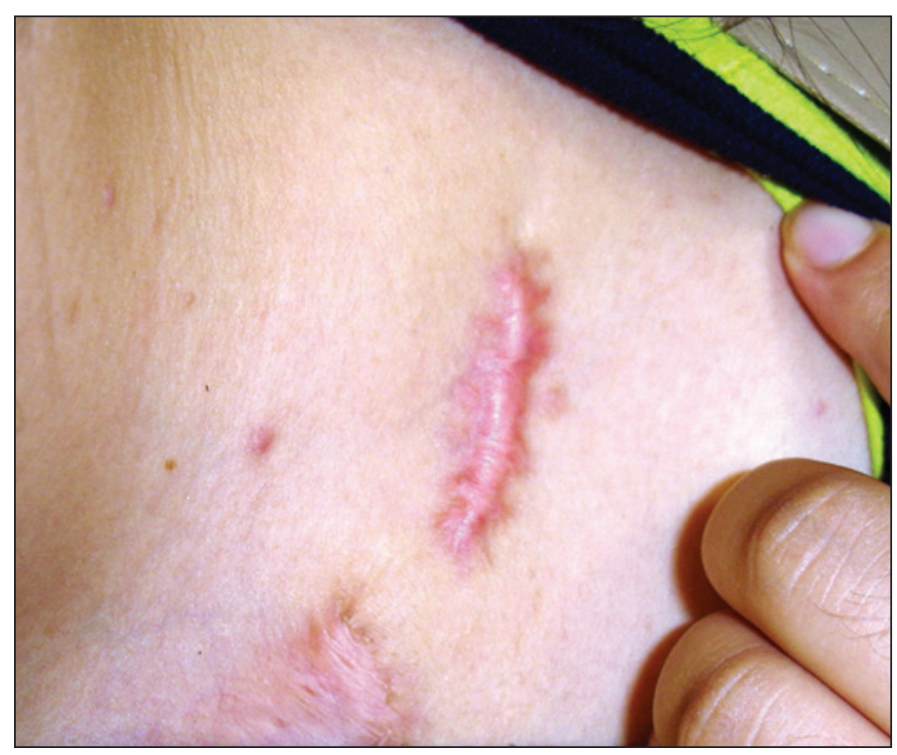

Figure 3 - Donor site hypertrophic scar

niques for cicatricial ectropion correction such as flap rotation or sub orbicularis oculi fat (SOOF) lift were not suitable in this case because of the extensive scarring around the inferior eyelid. The risks and benefits of the intervention must be discussed with the patient before surgery.
Although it's not possible to know in whom and when the pathergy phenomenon will occur, in the above reported case, eyelid surgery and skin graft harvesting was safely performed in a quiescent phase under corticosteroid.

\section{ACKNOWLEDGEMENTS}

To Tiago Lansini, MD for the pleasant support.

\section{RESUMO}

Paciente do sexo feminino de 19 anos com pioderma gangrenoso foi encaminhada ao setor de Plástica Ocular para avaliação de ectrópio cicatricial grave da pálpebra inferior direita. O exame evidenciou cicatrização importante na pálpebra inferior e região malar com um ectrópio secundário. Foi realizado liberação do tecido cicatricial e um enxerto de pele total associado a "tarsal strip". A dose de corticóide da paciente foi aumentada para a realização do procedimento e não houve problemas de cicatrização ou formação de úlceras na pálpebra ou no sítio doador após a cirurgia. Como o pioderma gangrenoso é associado ao fenômeno de patergia em até $25 \%$ dos casos, o surgimento de novas lesões é uma preocupação relevante ao indicar cirurgia nestes pacientes. Neste caso, a cirurgia foi realizada com segurança sob imunossupressão com corticóide.

Descritores: Pioderma gangrenoso; Ectrópio; Doenças palpebrais; Transplante de pele; Imunossupressão/uso terapêutico; Relatos de casos [Tipo de publicação]

\section{REFERENCES}

1. Su WP, Davis MP, Weenig RH, Powell FC, Perry HO. Pyoderma gangrenosum: clinicopathologic correlation and proposed diagnostic criteria. Int $\mathrm{J}$ Dermatol. 2004;43(11):790-800.

2. Vidal D, Puig L, Gilaberte M, Alomar A. Review of 26 cases of classical pyoderma gangrenosum: clinical and therapeutic features. J Dermatol Treat. 2004;15(3):46-52. Comment in: J Dermatol Treat. 2004;15(3):135.

3. Von Den Driesch P. Pyoderma gangrenosum: a report of 44 cases with follow-up. Br J Dermatol. 1997;137(6):1000-5.

4. Sapienza MS, Cohen S, Dimarino AJ. Treatment of pyoderma gangrenosum with infliximab in Crohn's disease. Dig Dis Sci. 2004;49(9):1454-7.

5. Dantzig PI. Pyoderma Gangrenosum. N Eng J Med. 1975;292(1):47-8

6. Wolff K, Goldsmith LA, Katz SI, Gilchrest BA, Paller A, Leffell DJ. Fitzpatrick's Dermatology in General Medicine. $7^{\text {th }}$ ed. New York; McGrawHill; 2007.

7. Rose GE, Barnes EA, Uddin JM. Pyoderma gangrenosum of the ocular adnexa: a rare condition with characteristic clinical appearances. Ophthalmology. 2003; 110(4):801-5.

8. Browning DJ, Proia AD, Sanfilippo FP. Pyoderma gangrenosum involving the eyelid. Arch Ophthalmol. 1985;103(4):551-2.

9. Newman WD, Frank HJ. Pyoderma gangrenosum of the orbit. Eye. 1993; 7(Pt 1):89-94.

10. Teasley LA, Foster CS, Baltatzis S. Sclerokeratitis and facial skin lesions: a case report of pyoderma gangrenosum and its response to dapsone therapy. Cornea. 2007;26(2):215-9.

11. Miserocchi E, Modorati G, Foster CS, Brancato R. Ocular and extracutaneous involvement in pyoderma gangrenosum. Ophthalmology. 2002;109(10): 1941-3. 